\title{
ANALYSIS OF SOCIAL MEDIA'S ACCESS; RELATION TO CHARACTER OF VOCATIONAL STUDENT IN BOGOR
}

\author{
Sudi Herlin Rahmawati ${ }^{\left.1^{*}\right)}$, Dwi Hastuti ${ }^{2}$, Tin Herawati ${ }^{2}$ \\ ${ }^{1}$ Program Studi IImu Keluarga dan Perkembangan Anak, Sekolah Pascasarjana, Institut Pertanian Bogor, \\ Bogor 16680, Indonesia \\ ${ }^{2}$ Departemen IImu Keluarga dan Konsumen, Fakultas Ekologi Manusia, Institut Pertanian Bogor, \\ Bogor 16680, Indonesia
}

${ }^{*}$ E-mail: herlin.rahma@gmail.com

\begin{abstract}
Recently, the existence of social media in Indonesia is consequence of acculturation both of culture and technology. This study aimed to analyze the relation of social media on the teenagers' character development, particularly responsibility, respectful, and courtesy. The observation was conducted in two vocational private high schools in Bogor, West Java Province. The selected schools were chosen as schools with high involvement on juvenile delinquency such as gang fight, drugs, and free-sex based on the data from local government official. Total participants were 100 students consist of 50 male and 50 female students at $1^{\text {st }}$ and $2^{\text {nd }}$ grade. Based on the analysis, there was significant difference between male and female student on accessing the social media (both on intensity and content). Females' scored higher than male in accessing Facebook, Twitter, YouTube, etc. On average, females' use of social media was between 2-3 hours per day, whereas for male it was only 1 hour. However, male had greater access to pornography than the females. The study found significant correlation between media social intensity and content access with the character. Highly teenagers' access to social media; correlate with the low of responsibility, respectful and courtesy character.
\end{abstract}

Keywords: pornography, respectful and courtesy, responsibility, social media, teenager

\section{Analisis Akses pada Sosial Media; Hubungannya dengan Perkembangan Karakter Siswa Sekolah Menengah Kejuruan di Bogor}

\begin{abstract}
Abstrak
Keberadaan media sosial di Indonesia saat ini merupakan hasil dari akulturasi budaya dan teknologi. Penelitian ini bertujuan untuk menganalisis pengaruh akses media sosial pada perkembangan karakter remaja, terutama karakter tanggung jawab, hormat dan santun. Penelitian dilakukan pada dua Sekolah Menengah Kejuruan (SMK) di Bogor, Provinsi Jawa Barat. Sekolah yang dipilih adalah sekolah dengan keterlibatan tinggi pada kenakalan remaja seperti perkelahian geng, narkoba, dan seks bebas berdasarkan data dari pejabat pemerintah setempat. Jumlah contoh sebanyak 100 siswa terdiri atas 50 laki-laki dan 50 siswa perempuan dari kelas 1 dan 2. Berdasarkan hasil analisis, terdapat perbedaan yang signifikan antara siswa laki-laki dan perempuan dalam mengakses media sosial (baik pada intensitas dan muatan yang terkandung). Siswa perempuan lebih sering mengakses Facebook, Twitter, YouTube, dll dibandingkan siswa laki-laki. Rata-rata perempuan mengakses media sosial selama 2-3 jam perhari, sedangkan siswa laki-laki hanya selama 1 jam. Namun, di sisi lain siswa laki-laki lebih sering mengakses muatan pornografi dibandingkan perempuan. Hasil penelitian menunjukkan adanya hubungan signifikan antara akses media sosial pada intensitas dan muatannya dengan karakter remaja. Hasil penelitian menunjukkan bahwa semakin sering remaja mengakses media sosial maka berhubungan dengan rendahnya karakter tanggung jawab, hormat dan santun remaja.
\end{abstract}

Kata kunci: hormat dan santun, media sosial, pornografi, remaja, tanggung jawab.

\section{INTRODUCTION}

Today, the existence of social media in Indonesia is the result of acculturation between culture and technology. Teenagers are rapidly influenced by the existence of social media and even actively accessing the contents (Montgomery, 2000). This is due to the teenage years as the period of development that have high curiosity as a result of development of growth hormone (Santrock, 2002). Hence, the presence of foreign cultures may influence the formation of teenager characters. Based on study by O'Keffe \& Pearson (2011), some problems may appear as a teenager accessing the social media will. For example, teenagers may experience online harassment (cyberbullying) or actively use foul and rude 
language when expressing opinions in cyberspace (online harassment). In addition, teenagers will also receive pornography or obscene picture (sexting) and have a desire to continuously monitor the comments from other friends in cyberspace (Facebook/twitter depression).

Currently, the access of the social media dominated by teenagers with age around 18 years old who spend 6 to 8 hours accessing the social media (Brow \& Cantor, 2000). Teenagers will express both the positive and negative emotions and behavior on the social media (Barnett et al., 2013). On the other hand, teenagers who actively access the social media tend to influence their friends in order to access the same media (Koutamanis et al., 2013). The most important thing that parents should be aware that the contents of internet generally contain violence and sexuality. Teenagers, who access the internet where social media is a part will be affected and imitated the contents. Aslanidou dan Menexes (2008) reported that male teenager were mainly access the internet for entertainment rather than seek a referral source for school assignments. In contrast, female teenagers were access mainly for the sake of learning science in school than for entertainment.

The study of Puspitawati (2009) in Bogor, showed that many teenagers are often involved in delinquency either individually or in groups. Those delinquencies such as leaving the house without asking permission from the parents, lying, skipping the school, do not admit fault, cheat, or against the wishes of parents. Other study reported, teenagers in Bogor were also involved in antisocial behavior such as smoking, consuming alcohol and drugs, have sex before married, involved brawl, and take action of bullying on a friend (Hastuti, Alfiasari, \& Sarwoprasodjo, 2012).

That condition was a sign of a setback for a nation. When teenagers are infected by phenomena such as the increasing use of blasphemy and profanity, the blurring of the guidelines between the good and the bad things, lack of respect to parents and teachers, the low sense of responsibility as individuals and citizens and increasing the value of the hatred, those mean that the nation is being decline (Lickona, 1991). It reflects that a teenager who has lost integrity of self or sense of responsibility indicated do not respectful and courtesy to parents (Peterson \& Seligman, 2004).
The character of a person will be shown during a decision-making process and the application of the decision (Megawangi, 2007). Therefore, it is very importance to educate a strong character to teenagers in order to be able to distinguish between what is permissible and which should be avoided. The most important character that teenagers must have are responsible, respectful and courtesy. The formation of character is very important and urgent to be noticed by parents to prevent, particularly related to the negative impact of social media.

Study by Hastuti, Alfiasari, \& Sarwoprasodjo (2012) in Bogor, on male and female teenagers found that 20 percent of teenagers were categorized as high in the score of responsibility, while the remaining $(70,0 \%)$ is grouped into the medium and low categories. In addition, the numbers of male and female teenagers who have high score in respectful and courtesy character were only 4 percent and the rest $(96,0 \%)$ have the score of in the middle and low categories.

The objectives of this research were to identify the access on intensity and content of social media as well as the character of responsibility, respectful and courtesy of teenagers; to analyze the differences in the intensity and contents access of social media as well as the character between male and female teenagers; and to analyze the correlation among the characteristics of teenagers and parents as well as the access of social media and the character of responsibility, respectful and courtesy of teenagers.

\section{METHODS}

The design of this study was cross sectional in which research site spread over two private vocational schools (SMK) that located both in the district and the city of Bogor, West Java, Indonesia. The period of the study, especially interview the students were conducted from October to December 2013. This research was part of the National Strategic Research 2012 entitled "Model of Role Harmonization between Family and School on Building of Honor Youth Character for the Achievement of Vision "Comprehensive Intelligent Man 2014".

The populations of this study were the whole selected vocational students. Determination of samples was done randomly from the population. The chosen schools were selected based on the high involvement of their 
students in juvenile delinquency such as fighting, drug use and free sex, according to the data from the local government official. The samples size was 100 students consist of 50 males and 50 females from grade 1 and 2 .

The data that have been collected in this study were the characteristics of teenagers, the characteristics of the parents, the intensity access of social media, the contents access of social media, and the character of responsible, respectful and courtesy. The data were collected through interviews guided by a structured questionnaire. The intensity and contents of social media measured by using an instrument that was adopted from Vandewater and Lee (2009) and Courtois et al. (2009). The character's instruments used in this study were adopted from Hastuti, Alfiasari, and Sarwoprasodjo (2012).

The data were processed through the editing, coding, sorting, entry and cleaning then analyzed using a computer program. Reliability test using Cronbach's alpha was performed for the questionnaire of the intensity and content of social media as well as the character. The data was presented into tabular form. Inferential statistical analysis that have been used in this study were (1) t-test, to analyze the differences on the intensity and content of social media access as well as the character between male and female students, (2) Pearson correlation test to analyze the relationships among the characteristics of teenagers and the parent as well as the intensity and content of social media access and teenagers characters.

\section{RESULTS}

\section{Teenager and Parent Characteristics}

The age of the participants was range between 14 to 19 years. The average age of male and female teenagers was not different. The average age of father's participants was 44,78 years old (male teenager) and 43,18 years (female teenager), while the average age of participant's mother was 39,80 years old (male teenager) and 39,06 years old (female teenager). The average family member of participants was 5 to 6 peoples, with the range between 3 to 12 people. The research found a significant difference in family size between male and female participants (provide statistics). The average family income of the participants was 2,26 million (male teenager) and 2,14 million (female teenager). The lowest family income was 1 million and the highest was 6 million rupiah (Table 1).
Table 1 Distribution of teenagers based on characteristic of student and parent

\begin{tabular}{|c|c|c|c|}
\hline \multirow[t]{2}{*}{ Characteristics } & \multicolumn{2}{|c|}{$\begin{array}{c}\text { Mean } \pm \text { Standard } \\
\text { deviation }\end{array}$} & \multirow[t]{2}{*}{$p$-value } \\
\hline & Male & Female & \\
\hline \multicolumn{4}{|l|}{ Student } \\
\hline Age (year) & $\begin{array}{r}16,08 \pm \\
0,94\end{array}$ & $\begin{array}{r}15,84 \pm \\
0,91\end{array}$ & 0,528 \\
\hline \multicolumn{4}{|l|}{ Parent } \\
\hline Father age (year) & $\begin{array}{r}44,78 \pm \\
9,66\end{array}$ & $\begin{array}{r}43,18 \pm \\
5,96\end{array}$ & 0,306 \\
\hline $\begin{array}{l}\text { Mother age } \\
\text { (year) }\end{array}$ & $\begin{array}{r}39,80 \pm \\
7,80\end{array}$ & $\begin{array}{r}39,06 \pm \\
5,10\end{array}$ & 0,502 \\
\hline $\begin{array}{l}\text { Father education } \\
\text { (year) }\end{array}$ & $\begin{array}{r}9,54 \pm \\
2,99\end{array}$ & $\begin{array}{r}8,12 \pm \\
3,42\end{array}$ & $0,030^{*}$ \\
\hline $\begin{array}{l}\text { Mother education } \\
\text { (year) }\end{array}$ & $\begin{array}{r}7,82 \pm \\
3,66\end{array}$ & $\begin{array}{r}7,88 \pm \\
3,70\end{array}$ & 0,935 \\
\hline $\begin{array}{l}\text { Member of } \\
\text { Family (people) }\end{array}$ & $\begin{array}{r}6,38 \pm \\
1,92\end{array}$ & $\begin{array}{r}5,58 \pm \\
1,60\end{array}$ & $0,026^{*}$ \\
\hline $\begin{array}{l}\text { Family income } \\
\text { (million } \\
\text { rupiah/month) }\end{array}$ & $\begin{array}{r}2,26 \pm \\
1,38\end{array}$ & $\begin{array}{r}2,14 \pm \\
9,74\end{array}$ & 0,618 \\
\hline
\end{tabular}

\section{Social Media}

Social media web access. Facebook $(19,9 \%)$, game online $(15,5 \%)$, dan youtube $(15,3 \%)$ were highly access by the the students. Mostly, the students access facebook than others. Base on gender, male students access games online more intensive than others web, while female student was more access youtube. Distribution of teenager based on social media web access are shown in Table 2.

Duration. Most of students spent 2-3 hours per day accessing the social media. On average, females' use of social media was between 2-3 hours per day, whereas for male it was only 1 hour. Distribution of teenager based on duration access on social media are shown in Table 3.

Table 2 Distribution of teenager based on social media web access

\begin{tabular}{lrrr}
\hline \multirow{2}{*}{ Social Media Access } & \multicolumn{2}{c}{ Gender } & \multirow{2}{*}{ Total } \\
\cline { 2 - 3 } & \multicolumn{1}{c}{$\%$} & \multicolumn{1}{c}{$\%$} & \multicolumn{1}{c}{$\%$} \\
\hline Facebook & 15,8 & 26,9 & 19,9 \\
Twitter & 11,1 & 16,5 & 13,1 \\
You tube & 12,3 & 20,3 & 15,3 \\
Blog & 9,2 & 4,9 & 7,6 \\
Instagram & 8,5 & 2,2 & 6,2 \\
Yahoo Massager & 9,8 & 5,2 & 8,2 \\
What's Up & 10,1 & 2,7 & 7,4 \\
Blackberry massager & 9,2 & 2,7 & 6,8 \\
Game online & 13,9 & 18,1 & 15,5 \\
\hline
\end{tabular}


Table 3 Distribution of teenager based on duration access on social media

\begin{tabular}{lccc}
\hline \multirow{2}{*}{$\begin{array}{l}\text { Duration Access on } \\
\text { Social Media }\end{array}$} & \multicolumn{2}{c}{ Gender } & Total \\
\cline { 2 - 3 } & $\begin{array}{c}\text { Male } \\
(\%)\end{array}$ & $\begin{array}{c}\text { Female } \\
(\%)\end{array}$ & \begin{tabular}{l} 
(\%) \\
\hline 0-30 minutes
\end{tabular} \\
1 hour & 46 & 26 & 18 \\
2-3 hours & 40 & 22 & 34 \\
$>4$ hours & 4 & 8 & 42 \\
\hline
\end{tabular}

Intensity. The social media intensity of teenager was very high. It showed from that many teenagers always accessing social media every day and always posts the online status every time. Teenagers also frequently access the social media while browsing the literature for a school assignment on Internet. Distribution of teenager based on intensity access of social media is depicted in Table 4.

Table 4 Distribution of teenager based on intensity access of social media

\begin{tabular}{|c|c|c|c|}
\hline \multirow[b]{2}{*}{$\begin{array}{l}\text { Intensity access of } \\
\text { social media }\end{array}$} & \multicolumn{2}{|c|}{ Gender } & \multirow[b]{2}{*}{$\begin{array}{l}\text { Total } \\
(\%)\end{array}$} \\
\hline & $\begin{array}{c}\text { Male } \\
(\%)\end{array}$ & $\begin{array}{c}\text { Female } \\
(\%)\end{array}$ & \\
\hline $\begin{array}{l}\text { Purchasing the } \\
\text { credit/renting the } \\
\text { internet while having } \\
\text { the money }\end{array}$ & 52,0 & 58,0 & 55,0 \\
\hline $\begin{array}{l}\text { Activating internet in } \\
\text { handphone }\end{array}$ & 64,0 & 52,0 & 58,0 \\
\hline $\begin{array}{l}\text { Impose the parent to } \\
\text { give the money for } \\
\text { accessing the internet }\end{array}$ & 14,0 & 42,0 & 28,0 \\
\hline $\begin{array}{l}\text { Access the social } \\
\text { media while browsing } \\
\text { school task through } \\
\text { internet }\end{array}$ & 76,0 & 88,0 & 82,0 \\
\hline $\begin{array}{l}\text { Update the "status" } \\
\text { every day }\end{array}$ & 62,0 & 68,0 & 65,0 \\
\hline $\begin{array}{l}\text { Change profile picture } \\
\text { more than once a week }\end{array}$ & 38,0 & 44,0 & 41,0 \\
\hline $\begin{array}{l}\text { Update the "status" } \\
\text { after completing an } \\
\text { activity }\end{array}$ & 42,0 & 66,0 & 54,0 \\
\hline $\begin{array}{l}\text { Update the "status" } \\
\text { while happy or sad }\end{array}$ & 58,0 & 76,0 & 67,0 \\
\hline $\begin{array}{l}\text { Unsteadiness before } \\
\text { update the "status" }\end{array}$ & 12,0 & 38,0 & 25,0 \\
\hline $\begin{array}{l}\text { Upload the picture of } \\
\text { daily activity }\end{array}$ & 10,0 & 32,0 & 21,0 \\
\hline $\begin{array}{l}\text { Add one fiend (contact } \\
\text { friend) every week }\end{array}$ & 72,0 & 78,0 & 75,0 \\
\hline $\begin{array}{l}\text { Monitoring comments } \\
\text { every day }\end{array}$ & 48,0 & 68,0 & 58,0 \\
\hline $\begin{array}{l}\text { Activating online status } \\
\text { at social media }\end{array}$ & 26,0 & 62,0 & 44,0 \\
\hline $\begin{array}{l}\text { Keep hungry, thirsty } \\
\text { and urinate while } \\
\text { accessing social media }\end{array}$ & 24,0 & 42,0 & 33,0 \\
\hline
\end{tabular}

Contents. The results showed that significant number of participants accessed the pornography contents such as watching porn video every week although despite they know it prohibited by the religion. Teenagers were also often access impolite words (disrespectful language) from social media to bullying or showed that they were angry with their teacher even their parent. Distribution of teenager based on content of social media is depicted in Table 5.

Table 5 Distribution of teenager based on content of social media

\begin{tabular}{|c|c|}
\hline & Gender \\
\hline Content of social media & $\begin{array}{c}\text { Female } \\
(\%)\end{array}$ \\
\hline
\end{tabular}

\section{Pornography}

Receiving the picture or porn video

Follow friends on watching picture and porn video

Watching porn video every week

Download porn video while accessing the internet

Save more than a picture and porn video

Upload intimate picture with girl/boy friend

Reading porn story

Always accessing porn

website although prohibited by religion

\section{Impolite language}

Knowing impolite words from social media

Reading impolite words of friends from social media

Have a temperamenta friend in social media

Have a friend in social media that always share the problem with his/her parent

Have a friend in social media that always bullying the teacher in the school

Have a friend in social

22,0 18,0

media that always

bullying his/her parents

Have a friend that

$\begin{array}{rrr}22,0 & 18,0 & 20,0 \\ 24,0 & 12,0 & 18,0 \\ & & \\ 36,0 & 6,0 & 21,0 \\ & & \\ 22,0 & 12,0 & 17,0 \\ & & \\ 14,0 & 10,0 & 12,0 \\ & & \\ 16,0 & 8,0 & 12,0 \\ & & \\ 14,0 & 12,0 & 13,0 \\ 20,0 & 26,0 & 23,0\end{array}$

always using impolite

$76,0 \quad 78,0 \quad 77,0$

$68,0 \quad 80,0 \quad 74,0$

$80,0 \quad 80,0 \quad 70,0$

$52,0 \quad 62,0 \quad 57,0$

words in social media

Note:

$\%=$ Percentage 
Table 6 Descriptive statistics of social media variables between male and female

\begin{tabular}{lccc}
\hline \multirow{2}{*}{ Social Media } & \multicolumn{2}{c}{$\begin{array}{c}\text { Mean } \pm \text { Standard } \\
\text { Deviation }\end{array}$} & p-value \\
\cline { 2 - 3 } & Male & Female & \\
\hline Intensity & $44,0 \pm 7,5$ & $48,4 \pm 10,3$ & $0,018^{*}$ \\
Content & & & \\
Pornography & $23,5 \pm 5,6$ & $20,3 \pm 5,8$ & $0,006^{* *}$ \\
Impolite words & $20,9 \pm 3,6$ & $21,2 \pm 5,3$ & 0,692 \\
\hline Note: *Significance at $p<0,05,{ }^{* *}$ Significance at $p<0,01$
\end{tabular}

\section{The Difference between Male and Female} Teenagers

The result showed that there were differences between male and female teenagers related to the intensity of accessing the social media, where female are more intensive than male. The research also found the differences on accessing pornography contents between male and female teenagers, where male tend to be more frequently access the pornography than female (Table 6).

Table 7 Distribution of teenager based on character

\begin{tabular}{|c|c|c|c|}
\hline \multirow[b]{2}{*}{ Character } & \multicolumn{2}{|c|}{ Gender } & \multirow[b]{2}{*}{$\begin{array}{c}\text { Total } \\
(\%)\end{array}$} \\
\hline & $\begin{array}{c}\text { Male } \\
(\%)\end{array}$ & $\begin{array}{c}\text { Female } \\
(\%)\end{array}$ & \\
\hline \multicolumn{4}{|l|}{ Responsibility } \\
\hline $\begin{array}{l}\text { Type media status while } \\
\text { teacher was teaching }\end{array}$ & 38,0 & 40,0 & 19,0 \\
\hline $\begin{array}{l}\text { Type like online status } \\
\text { while teacher was } \\
\text { teaching }\end{array}$ & 46,0 & 48,0 & 23,0 \\
\hline $\begin{array}{l}\text { Uses internet access for } \\
\text { social media often than } \\
\text { for school task }\end{array}$ & 46,0 & 28,0 & 23,0 \\
\hline $\begin{array}{l}\text { Enjoy to access social } \\
\text { media than to do the } \\
\text { school homework } \\
\text { Respectful and } \\
\text { Courtesy }\end{array}$ & 42,0 & 42,0 & 21,0 \\
\hline $\begin{array}{l}\text { While access the social } \\
\text { media didn't listen while } \\
\text { parents' talking to me }\end{array}$ & 16,0 & 26,0 & 8,0 \\
\hline $\begin{array}{l}\text { Copying un appropriate } \\
\text { word (from online } \\
\text { Disrespectful language) } \\
\text { to talk with parent and } \\
\text { teacher }\end{array}$ & 20,0 & 22,0 & 10,0 \\
\hline $\begin{array}{l}\text { Copying un appropriate } \\
\text { word (from online } \\
\text { Disrespectful language) } \\
\text { to send instant message } \\
\text { for parent and teacher }\end{array}$ & 14,0 & 20,0 & 7,0 \\
\hline $\begin{array}{l}\text { Inspired from online } \\
\text { status to ignore parent }\end{array}$ & 14,0 & 8,0 & 7,0 \\
\hline $\begin{array}{l}\text { Ignore the rules from } \\
\text { parent to turn off the } \\
\text { social media while } \\
\text { studying at home }\end{array}$ & 22,0 & 24,0 & 11,0 \\
\hline $\begin{array}{l}\text { Inspired from online } \\
\text { status to against parent }\end{array}$ & 10,0 & 8,0 & 5,0 \\
\hline
\end{tabular}

Table 8 Descriptive statistics of teenager character variable of male and female

\begin{tabular}{lccc}
\hline \multirow{2}{*}{ Character } & \multicolumn{2}{c}{$\begin{array}{c}\text { Mean } \pm \text { Standard } \\
\text { Deviation }\end{array}$} & \multirow{2}{*}{\begin{tabular}{c}
$p-$ \\
\cline { 2 - 3 } value
\end{tabular}} \\
\cline { 2 - 3 } & Male & Female & \\
\hline Responsibility & $55,1 \pm 21,1$ & $70,0 \pm 16,1$ & $0,018^{*}$ \\
$\begin{array}{l}\text { Respectful } \\
\text { and courtesy }\end{array}$ & $62,1 \pm 25,5$ & $73,2 \pm 17,2$ & 0,319 \\
\hline
\end{tabular}

\section{Character}

The score of participants' responsibility, respectful, and courtesy were tend to low. This showed the teenagers were still keep on type like online status although teacher was teaching in the class and uses internet access for social media often than for school task. The participants' also still ignore the rules from parent to turn-off the social media while studying at home and copying un appropriate word (from online disrespectful language) to talk with parent and teacher (Table 7).

\section{The Differences between Male and Female Teenagers}

Previous studies in Bogor showed that female students have more good character than male students (Karina, Hastuti, \& Alfiasari, 2013). In this study there were significant differences in the quality of the characters of male and female teenagers related to responsibility. The research showed that male students have higher responsibility than female (Table 8).

\section{Relationship between Characteristics of Teenager and Parent with Intensity and Contents of Social Media Access on Character of Teenager}

Based on correlation analysis, there was significant correlation between porn and impolite words contents of social media that accessed by teens with the score of both responsibility and respectful and courtesy. The analysis showed that when student access content porn such as watching porn video every week although despite they know it is prohibited by the religion and impolite words; they higher to type like online status although teacher was teaching and uses internet access for social media often than for school. The participants' also higher ignore the rules from parent to turnoff the social media while studying at home and copying un appropriate word (from online disrespectful language) to talk with parent and teacher (Table 9). 
Table 9 Correlation result between teenager and family characteristic with the intensity and content of social media

\begin{tabular}{|c|c|c|}
\hline \multirow[b]{2}{*}{ Variable } & \multicolumn{2}{|c|}{ Character } \\
\hline & Responsible & $\begin{array}{l}\text { Respectful } \\
\text { and } \\
\text { Courtesy }\end{array}$ \\
\hline \multicolumn{3}{|l|}{ Student characteristics } \\
\hline $\begin{array}{l}\text { - Gender }(0=\text { male, } 1= \\
\text { female) }\end{array}$ & $-0,149$ & $-0,097$ \\
\hline - Age & $-0,131$ & 0,048 \\
\hline \multicolumn{3}{|l|}{ Parent characteristic } \\
\hline - Age of father & $-0,118$ & $-0,109$ \\
\hline - Age of mother & 0,057 & $-0,025$ \\
\hline - Education of father & $-0,003$ & 0,027 \\
\hline - Education of mother & $-0,070$ & $-0,077$ \\
\hline - Family size & 0,083 & $-0,021$ \\
\hline - Family income & $-0,053$ & 0,018 \\
\hline \multicolumn{3}{|l|}{ Social Media } \\
\hline - Intensity & $0,235^{\star}$ & $0,248^{*}$ \\
\hline $\begin{array}{l}\text { - Porn and impolite } \\
\text { words content }\end{array}$ & $0,313^{\star *}$ & $0,271^{* *}$ \\
\hline
\end{tabular}

\section{DISCUSSION}

The access to the social media on teenagers both their intensity and the content (pornography and impolite words) has correlation with the establishment of students' characters. This finding relate to the research Subrahmanyama et al. (2001) that teenagers who high access to the social media lead to have negative behaviour such as spent the daily time in front of the computer and ignored other daily activities.

The students were rapidly accessed social media every day which actively written their activities. Some of the students were every time type status on social media. When teenagers highly access the social media, related to Kountamanis et al. (2013), they will persuade others to access the same media. Social media and peers were close environment to the teenagers' life. Bronfenbrenner in Bern (1997) said that the nearest environment such as media and peers as microsystem that will directly influence to the teenagers life. Based on the result, we assume that the high teenagers access on social media were influenced by the circumstance on social media which was persuade from peer to access the social media.

The results showed that there were differences between male and female related to the intensity of accessing the social media, where female are more intensive than male.
Kaplan dan Heinlein (2009) said that people use social media was to share information about their daily life to others (open diary). Related to the research, female more intensively share information on social media than male. This finding support by Koenigsknecht \& Friedman (1978) who said that female eager to share as many as information fot other than male, girls more frequent use their verbal skill than boys. This characteristic significantly influence the female more frequently accesing the social media to share their daily life than male.

Many students were also access pornography contents even though they know that it prohibited by religion. When student access the porn content will lead to the emergence of behavioral problems such as shirking responsibility, and undertaking deviant behavior like sending pornography picture through social media ( $O$ 'Keefe \& Pearson, 2011).

Beside pornography, the students also access impolite words (disrespectful language). They often access impolite words from social media to bullying or showed that they were angry with their teacher even their parent. When teenagers access to social media they tent to express their feeling and emotion; both of positive and negative (Barnet et al. 2013). This condition will access by others teenagers, and the others intentionally eager to imitate the same expression. The impolite words content on social media as microsystem. It will influence the teenagers' behavior (Bronfenbrenner inside Bern, 1997).

The research also found the differences on accessing pornography contents between male and female teenagers, where male tend to be more frequently access the pornography than female. Based on previous research, boys intensively access pornography than girls Flood (2007). This condition were influence by the "genital" sexuality development of male student. On the "genital" period, male begin to face about "first ejaculation of sperm". Based on Freud in Miller (2011) this condition will stimulate for male to do sexuality activity, related to this research was about to access the pornography. This situation were different in female sexuality development.

The score of participants' responsibility, respectful and courtesy tend to low. This shown that the teenagers still typed like in online status, although the teacher was teaching. They also use internet access for social media more 
often than for school study. The participants' also still ignore the rules from parent to turn-off the social media while studying at home and copying un appropriate word (from online disrespectful language) to talk with parent and teacher. This result shown that their cognitive was low, refer to the Piaget moral theory said that when people has low cognitive skill will influence to the low of moral character (Piaget in Santrock, 2002).

The study showed that, there were significant differences in the quality of the characters of male and female teenagers related to responsibility where male students have higher responsibility than female. Previous studied in Bogor showed that female students have more good character than male students (Karina, Hastuti, \& Alfiasari, 2013). This differ result showed there were changing in female development. Based on the result, female student were intensively more access social media than male. This result correlated to the low of the responsible character on female. Subrahmanyama et al (2001) confirmed that the higher of teenagers access the media sosial impact to the behaviour of teenagers. They tend to spend more time on accaessing the social media than to do productive activity such as doing the school task or playing outdoor. The higher they acccess social media, the lower of character developt.

\section{CONCLUSION AND SUGGESTION}

Teenagers still access the social media that contain pornography despite knowing prohibited by religion. Teenagers also have friends on social media that often do not speak politely through social media. There were differences in the intensity and content of pornography between male and female teenagers. Female more intensive access the social media, this condition correlate to the female character that less responsible than male. Parents should provide control through socialization for teenagers related to the intensity and content in the social media access. More in-depth follow-up study of the analysis through the social media access is needed.

\section{ACKNOWLEDGEMENT}

Many thanks to the research Team of National Strategic Research (STRANAS Project) 2012 entitled "Model of Role Harmonization between Family and School on Building of Honor Youth Character for the Achievement of Vision "Comprehensive
Intelligent Man 2014" who lead by Dr. Ir. Dwi Hastuti, MSc.

\section{REFERENCES}

Aslanidou, S., \& Menexes, G. (2008). Youth and the internet: Uses and practices in the home. Computers \& Education Journal, 51, 1375-1391.

Barnett, M., Nichols, M. B., Sonnentag, T. L., \& Wadian, T. W. (2013). Factors associated with early teenagers' anticipated emotional and behavioral responses to ambiguous teases on facebook. Computers in Human Behavior Journal, 29, 2225-2229.

Bern, R. M. (1997). Child, family, school, community socualization and support. California, US: Harcourt Brace College Publishers.

Brow, J., \& Cantor, J. (2000). An agenda for research on youth and the media. Journal of Teenager Health, 27, 2-7.

Courtois, C., Mechant, P., De Marez, L., \& Verleye, G. (2009). Gratification and seeding behavior of online adolescents. Journal of Computer Mediated Communication, 15(1), 109-137. doi:10.111/j.1083-61012009.01496.x.

Flood, M. (2007). Exposure to pornography among youth in Australia. Journal of Sociology, 43(1), 45-60. doi:10.1177/1440783307073934.

Hastuti, D., Alfiasari, \& Sarwoprasodjo, S. (2012). Model harmonisasi peran keluarga dan sekolah dalam pembentukan karakter mulia remaja bagi tercapainya Visi "Insan Cerdas Komprehensif Tahun 2014". Institut Pertanian Bogor, Bogor

Kaplan, A. M., \& Haenlein, M. (2009). Users of the world, unite the challenges and opportunities of social media. Journal of Business doi:10.1016/j.bushor.2009.09.003

Karina, Hastuti, D., \& Alfiasari. (2013). Perilaku bullying, perilaku karakter remaja serta kaitanya dengan karakteristik keluarga dan peer group. Jur. IIm. Kel. \& Kons., 6(1), 2029.

Koenigsknecht, R. A., \& Friedman, P. (1976). Syntax development in boys and girls. Child Development, 47, 1109-1115

Koutamanis, M., Vossen, H. G. M., Peter, J., \& Valkenburg, P.M. (2013). Practice makes perfect: The longitudinal effect of teenagers' instant messaging on their 
ability to initiate offline friendships. Computers in Human Behavior Journal, 29, 2265-2272.

Lickona, T. (1991). Educating for character: How our schools can teach respect and Responsibility. New York, US: Bantam Books.

Megawangi, R. (2007). Sembilan pilar: Percaya diri dan tanggung jawab. Depok, ID: Indonesian Heritage Foundation.

Miller, P. H. (2011). Theories of developmental psychology. Fifth edition. New York, US: Worth Publishers.

Montgomery, K. (2000). Youth and digital media: A policy research agenda. Journal of Teenager Health, 27(2) 61-68.

O'Keeffe, G. S., Pearson, K. C. (2011). The impact of social media on children, teenagers, and families (council on communications and media). Pediatrics Journal, 127.

Peterson, C., \& Seligman, M. E. P. (2004). Character strenghts and virtues: $A$ handbook of classification. New York, US: Oxford University Press.

Puspitawati, H. (2009). Kenakalan remaja dipengaruhi oleh sistem sekolah dan remaja. Bogor, ID: IPB Press.

Santrock, J. W. (2002). Life span development. $8^{\text {th }}$ Edition. New York, US: McGraw Hill.

Subrahmanyam, K., Greenfield, P., Kraut, R., \& Gross, E. (2001). The impact of computer use on children's and adolescents' development. Applied Development Psychology, 22, 7-30.

Vandewater, E. A., \& Lee, S. J. (2009). Measuring children's media use in digital age. Am Behav Sci. 52(8), 1152-1176. doi:10.1177/0002764209331539. 